This item was submitted to Loughborough's Research Repository by the author.

Items in Figshare are protected by copyright, with all rights reserved, unless otherwise indicated.

\title{
Abraham Tucker as an 18th-century William James: stream of consciousness, role of examples, and the importance of writing
}

PLEASE CITE THE PUBLISHED VERSION

http://dx.doi.org/10.1177/0959354311398518

\section{PUBLISHER}

(c) Sage

\section{VERSION}

AM (Accepted Manuscript)

\section{LICENCE}

CC BY-NC-ND 4.0

\section{REPOSITORY RECORD}

Billig, Michael. 2019. "Abraham Tucker as an 18th-century William James: Stream of Consciousness, Role of Examples, and the Importance of Writing". figshare. https://hdl.handle.net/2134/13362. 
This item was submitted to Loughborough's Institutional Repository (https://dspace.lboro.ac.uk/) by the author and is made available under the following Creative Commons Licence conditions.

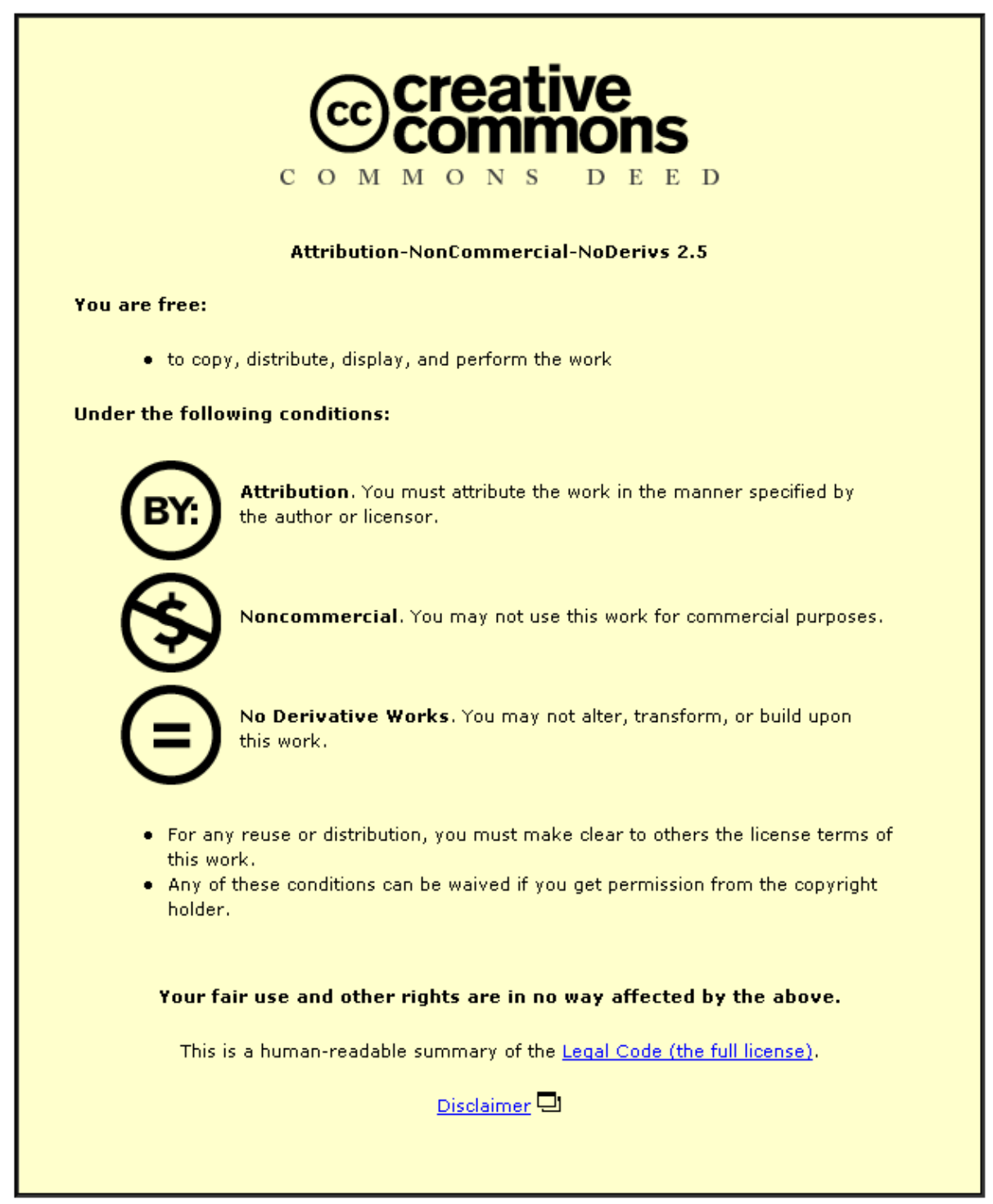

For the full text of this licence, please go to: http://creativecommons.org/licenses/by-nc-nd/2.5/ 
Abraham Tucker: an eighteenth century William James 


\author{
Michael Billig \\ Department of Social Sciences \\ Loughborough University \\ Loughborough \\ LE11 3TU \\ United Kingdom
}

Biographical note.

Michael Billig is professor of Social Sciences, Loughborough University and a member of the Loughborough Discourse and Rhetoric Group. His background is in social psychology. He has published books on a number of subjects including social psychological theory, nationalism, and psychoanalysis. His recent books include

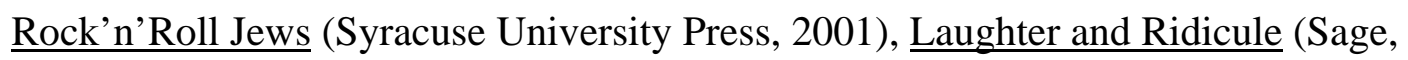
2005) and The Hidden History of Critical Psychology (Sage, 2008). 
Abstract

This article discusses the psychological writings of the neglected, eighteenth century English philosopher, Abraham Tucker. The article explores the similarities between Tucker's work and that of William James. It is suggested that both share a humorous and humane style, which concentrates on exploring concrete examples, especially from everyday life, rather than constructing abstract theories. Moreover, there are a number substantive similarities. Tucker, like James, saw consciousness occurring over time as a river or stream. Both stressed the importance of habit for individual and social life; and both depicted the infant as being overwhelmed by sensation. Several reasons for Tucker’s neglect are suggested. He may have been 'dethroning' the ideal of the conscious, rational ego before the importance of unconscious thinking had gained currency. It is argued that in celebrating Tucker and James as psychologists, we are emphasising the importance of warm-hearted writing as against rigid theory and methodology.

Key words: Abraham Tucker, William James, consciousness, rhetoric, history of psychology 
“I have always held the opinion”, wrote William James, "that one of the first duties of a good reader is to summon other readers to the enjoyment of any unknown author of rare quality whom he may discover in his explorations” (1911, p. 371). James was writing about an unjustly neglected contemporary. It is also possible to stumble across a long dead writer of rare quality, who seems to have been generally overlooked. Practically no books on the history of psychology - from the early Baldwin (1913) and Boring (1929) to the recent Richards (2002) and Robinson (1996) - even mention Abraham Tucker (1705-1774), let alone discuss his originality. Martin and Barresi (2000) are a notable exception, but for most students of psychology’s history Tucker remains a pleasure yet to be discovered.

Introducing a discussion of Tucker with a quotation from William James is not a chance act. In this article, I have two main objectives. First, I wish to act as James’s good reader, sharing my enjoyment and admiration of Tucker. Second, I want to suggest that Tucker resembles James both with respect to specific psychological ideas and also in his general approach. William James, of course, is not a neglected figure. He was admired by such diverse psychologists, such as Boring, Vygotsky and Watson (Leary, 1990). He continues to be lauded. According to Damasio (2006), only Shakespeare and Freud equal James’s understanding of human behaviour.

James was, of course, widely praised by his contemporaries. The philosopher F.C.S. Schiller claimed that James, in describing consciousness as a stream, had made "a great discovery” (1996, p. 149). James Angell, James’s research assistant at Harvard 
and later professor of psychology at the University of Chicago, pointed to the concept of habit as "the most important interpretative principle” running through James’s work (1996, p. 135). Angell described The Principles of Psychology as "perhaps the only thoroughly entertaining account of reasoning that we have in the English language” (p.136). In these three matters - seeing consciousness as a stream, insisting on the psychological importance of habit, and writing in a humane, amusing manner James had an eighteenth century forebear: Abraham Tucker.

One point should be stressed at the outset. In depicting Tucker as an early Jamesian, I am not implying in any way that James plagiarized the eighteenth century writer. James was far too intellectually honest ever to do that. And Tucker was far too neglected a figure for us to assume that James might have been familiar with his work. The similarities in their thinking raise much more interesting issues than plagiarism.

\section{The Life of Tucker}

Abraham Tucker led an uneventful life. He did not move in the intellectual circles of the age. Unlike most other notable thinkers in eighteenth century Britain, he does not crop up in Boswell’s record of Samuel Johnson’s life. Nor did Tucker correspond with philosophical contemporaries in continental Europe. For the most part, he lived quietly in Surrey on a large country estate. Most of the information about his life comes from a very brief biography which his grandson, St John Mildmay, wrote as a preface for a republication of Tucker's major work The Light of Nature Pursued (see also Young, 2004). Tucker’s father, a wealthy merchant, died when Tucker was still a 
child. Having inherited the family fortune, Tucker never needed to seek a university or clerical position; nor did he rely on the sales of his books for an income. That distinguished him from contemporaries, such as Hume, Hartley and Reid, all of whom figure much more prominently in the histories of psychology. Unwilling to engage in public controversy and reluctant to push himself forward, Tucker preferred to stay at home, pursuing his intellectual interests and attending to the education of his two daughters.

Tucker published nothing under his own name. He published two minor tracts (1755 and 1773) - the first, an anonymous light-hearted piece, supposedly written by a country gentleman advising his son to avoid politics; and the second, a pseudonymous booklet suggesting how spelling could be reformed phonetically to match the spoken word. Apart from these, Tucker’s literary efforts were devoted to Light of Nature, which he started in 1756, two years after the death of his much missed wife. He published a lengthy, preliminary chapter on freewill as a separate booklet in 1763, under the pseudonym of Edward Search. This booklet, Freewill, Foreknowledge and Fate also contained a preface by Tucker’s other pseudonymous self, 'Cuthbert Comment', who described himself as Edward's cousin and a member of “an under branch of the Searches” (Tucker, 1763a, p. xxv). In the main text Mr Comment also added several footnotes. Following a critical review of Freewill in Monthly Review, Mr Comment came to the spirited but good humoured defence of his cousin in a separate booklet (Tucker, 1763b). The first two parts (comprising five books) of Light of Nature were published in 1768, under the name of Edward Search; these had no editorial interventions from Cuthbert Comment. 
Tucker continued working on his great opus, finishing it shortly before his death in 1774. The last years were difficult. He had gone blind, but his older daughter, Judith, helped him complete the work, transcribing his words and reading drafts back to her father. She even taught herself ancient Greek in order to help with the task. Judith oversaw the posthumous publication of the final four books. She discarded her father's literary conceit of being Search or Comment, publishing these volumes under his own name.

Tucker may have been mourned by family and friends, but his death hardly bothered the outside world. The Annual Register, which had not reviewed Tucker's work in 1768, failed to mention him in their list of notable deaths for 1784 . They recorded the death of the town clerk for the City of London, who died a few days before Tucker; and then they listed the death of a co-heiress to a Lincolnshire land-owner, who died a week later. In between these two listings, there is nothing to record the passing of the author of Light of Nature (Annual Register, 1775, pp. 198-9). Tucker’s importance ranked beneath that of a town clerk and provincial co-heiress.

\section{$\underline{\text { Tucker's Project }}$}

Even Tucker's most dedicated admirers will admit that Light of Nature is not a tightly structured work. It digresses, as Tucker allows his imagination to wander down some quirky by-ways. This is particularly pronounced in the last volumes, which were written when the author could no longer read his own drafts or earlier chapters. Nevertheless, his basic project is clear: he wished to present a case for rational Christianity, opposing both materialist atheism and the bigotry of unreasoning faith. 
Rational Christianity for Tucker meant faith rooted in a rational understanding of nature. God had established "the laws of nature” and so any Christian philosophy “proceeds by the study of nature”, including human nature (Tucker, 1843, p. 462). (1) The first part of Light of Nature was subtitled 'Human Nature' whilst the second part was 'Theology': the volumes published posthumously bore the subtitle 'Lights of Nature and Gospel Blended’.

For his analysis of human nature, and particularly for his analysis of human thinking, Tucker drew inspiration from Locke’s Essay Concerning Human Understanding. In the Introduction to Light of Nature, Tucker modestly claimed that "whatever I may be able to do I stand in indebted to Mr Locke”, who had facilitated the increase of knowledge "by pointing out the sources and channels from whence it must be derived”. However greatly Tucker venerated Locke, he nevertheless found himself at liberty "to dissent from him in some few instances”, adding that "this happens very seldom” (1768, I, ii, pp. xviii-xix). Despite this, Tucker’s differences from Locke are of great significance in terms of psychological understanding.

One of Tucker's contemporaries, David Hartley, also attempted to build upon Locke’s analysis of the mind as a means of exploring human nature and building a form of rational Christianity. Hartley’s Observations on Man, which was published twenty years before the first part of Light of Nature, also had two parts: the first an analysis of human psychology and the second a theological analysis supposedly based on the first part. Hartley’s approach was much more systematic than Tucker’s. Hartley analysed the human mind in terms of the principle of association, which he derived from Locke. He combined this with a theoretical neuropsychology, based on the 
passage of vibrations along the nervous system - an idea, which he claimed was derived from Newton.

Despite certain outward similarities between Hartley’s work and his own, Tucker was critical of Observations. He distrusted Hartley's theory of vibrations, viewing it as fundamentally materialist. According to Tucker, Hartley was reducing human action to the laws of physiology and was thereby denying free-will (1768, I, ii, pp. 66ff). Unlike Tucker, Hartley was a systematiser, trying to organize all human psychology including both the psychology of thinking and of the emotions - around the principles (or what he called the 'doctrines') of association and neurological vibration. Historians of psychology, recognizing something familiar in Hartley’s style of neuropsychological theorising, have often credited him with being one of the first ‘proper’, scientific psychologists (e.g., Glassman and Buckingham, 2007; Goodwin, 2004; Hergenhahn, 2001; Wade, 2005; Wertheimer, 1987). In praising Hartley for anticipating neuropsychology, or psychobiology, or concepts such as 'the reflex arc', these historians have tended to ignore the religious, even mystical, aspects of Observations (on Hartley’s theology, see Allen, 1999; Ulmer, 2006).

Tucker might have criticised Hartley for being a materialist, but he also stressed that human experience required a body. Without eyes, ears and nervous connections to the brain, we would not be able to see or hear (1768, II, ii, pp. 7ff). Tucker was aware that this assumption contained theological perils. If the body is necessary for experience, then this would mean that there could be no conscious life after the death of the body. In the theological part of Light of Nature, Tucker produced a mystical 'hypothesis', proposing that on death the soul departs from the body in a tiny bodily vehicle, that is 
too small to be seen by the naked eye. The soul continues to exist in this vehicular state until it ultimately progresses to the 'mundane state', when it loses its individuality and becomes at one with all previous souls. Tucker describes his vision of having met the vehicular, John Locke. The dead philosopher, now inhabiting a tiny body, greets him warmly: "Welcome, Ned Search, into the vehicular state...I have noticed a faint resemblance in your way of thinking with mine” (1768, II, ii, p. 127). Tucker (or Search) then has an enjoyable chat with Locke about matters philosophical and vehicular. Locke explains how he can still speak, despite lacking a mouth between his vehicular nose and enormous chin. As James would do many years later, Tucker takes mystical themes seriously without abandoning good sense or down-toearth humour (see, particularly, James, 1908, and his defence of entertaining unproven religious hypotheses).

I will not be discussing these aspects of Tucker's work (but see Martin and Barresi, 2000, for an excellent discussion of Tucker's ideas about the unity of the person). Nor will the present discussion deal with the theme that brought Tucker a little bit of posthumous fame, which perhaps, in the company of the vehicular Locke, he might have been able to observe with enjoyment. In the early part of the nineteenth century, William Paley became the most important ethical philosopher in England. He advocated a sort of Christian utilitarianism. Tucker had argued that humans do not only pursue individual pleasure or happiness, as Locke had implied, but they also pursue, or rather should pursue, the common happiness of all (see particularly, Chapter One of Tucker, 1777). Paley in his Principles of Moral and Political Philosophy, paid tribute to Tucker: "I have found in this writer more original thinking and observation upon the several subjects that he has taken in hand than in any other, 
not to say, than in all others put together”. Interestingly, Paley explained who Tucker was and how the Light of Nature came to be published, as if he did not expect his readers to recognize the author's name (Paley, 1791, pp. xxv-xxvi).

Paley also mentioned that Tucker's book was diffuse, his thoughts being "spread over too much surface”; nevertheless, "his talent for illustration is unrivalled” (Paley, 1791, p. xxvi). Tucker's social utilitarianism may not be relevant to the present discussion, but his talent for illustration most certainly is. It shaped the character of his psychological analyses, and puts him at one with William James.

\section{$\underline{\text { Tucker's Style and Approach }}$}

In the preface 'To the Reader' of the booklet, Freewill, Foreknowledge, Tucker wrote about his approach, aims and literary style. He said that he neither expected nor sought applause for his writing: "the Searches were never remarkable for a fondness for fame” (1763a, p. xiv). Although he worked in isolation, he took great care with his writing: "I am sure it has cost me infinite pains to save pains to my Reader” (p. xviii). Because his topics were "unentertaining and dry", he endeavoured "to embellish them with a diversity of style" in order to "to relieve the Reader and keep his attention awake” (p. xiii). Sometimes he treated his Reader as a friend, “as if we were sitting together over a bottle” (p. xiv). In the 'Preface of the Annotator', Cuthbert Comment, himself a literary embellishment, commented that "few since Plato have attempted to intersperse humour and gaiety among close arguments” (p. xxvii). The mixing of humour and religion, continued Comment, might cause offence, for, both, "though were agreeable in themselves", could suffer "by their commixture, as tea and snuff 
laid in the same drawer spoil one another’s flavour” (p. xxvii). Tucker would have known that overly pious readers would not welcome religion being compared with tea or snuff.

Interspersing argument with humour was also characteristic of James’s style. Hugo Münsterberg wrote that James’s textbooks have "the intimate warmth of a friend" and "the charm of a perfect artist”; students read them as if reading a novel. (Münsterberg 1996, p. 109). One historian of psychology has claimed that James’s Principles contains the richest descriptions of human experience in non-fictional writing (Wozniak, 1999). There was an oft repeated saying about the James brothers: William wrote psychology like a novelist, while his Henry wrote novels like a psychologist. Both psychologists and literary critics have continued to repeat the saying (e.g., Gregory, 1994, p. 179; Crawford et al, 2007, p. 211; the comparison can be traced to Rebecca West, 1916, p.11). Tucker, however, cautioned his Reader, not to read his work as if it were a novel "where one has little else to do than drive on post haste to see how it ends" (1763a, p. xxi).

There was a reason why James might have been read as if a novelist, and why Tucker considered that this might have been a possibility. Quite apart from their respective literary skills - and the trouble they took to acquire such skills - both James and Tucker placed great emphasis on describing examples. Like novelists, they gave primacy to the particular, rather than treating particulars as the mere servants of theory. Tucker outlined this in his preface to the Reader. He sought understanding through “experience and observation of ourselves” (1763a, p. vii), examining the workings of the mind "in the common occurrencies of life” (p. viii). He counselled his 
hypothetical reader "to judge of the abstract in the concrete" and to fix upon “particular instances” (p. xxii). James’s recent biographer has commented that it is “the parade of examples” that brings Varieties of Religious Experience to life (Richardson, 2007, p. 414: see also Taylor, 2007).

James and Tucker reflected on their own feelings with humanity and modesty. They did not describe the philosophical ego triumphing over ignorance. In one of the most famous passages of Principles, James describes how he found it difficult to get out of bed on a cold morning. He writes that, "if I may generalize from my own experience”, we suddenly find ourselves having got up without a decision - "a fortunate lapse of consciousness has occurred” (1890, vol. II, p. 524). Similarly, James described his problems in concentrating. He shares his readers’ weaknesses; and so did Tucker. Criticising Locke's claim that a good student only leaves his studies to satisfy an appetite, Tucker says that after a morning's work on his book, he finds himself in need of recreation:

"I then throw aside my papers sometime before dinner; the veriest trifle suits my purpose best: the philosopher can loll out at window like Miss Gawkey, to see the wheelbarrow trundle, or the butcher's dog carry the tray, and is perfectly contented with his situation” (1768, 1, i, p. 140).

Then the dinner bell sounds and the gawking philosopher runs down to the parlour.

Most of Tucker's disagreements with Locke came when he examined particular examples in detail. This is clear when Tucker discussed motives in Chapter VI of 
Light of Nature. Locke in his Essay had produced a rather sketchy account of human motivation, based on the search for pleasure and the avoidance of pain (e.g. 1690/1960, II, xx-xxii, pp.159ff). Pleasures and pains create uneasiness, and we are motivated to remove that uneasiness and seek satisfaction - hence we engage in motivated actions. Tucker saw great merit in Locke's account, but he felt it was limited. To be sure there were moments of uneasiness leading us to satisfy desires, but not all our actions stemmed from uneasiness.

Locke had concentrated on important actions in life, rather than common occurrences. Tucker saw that we are continually filling our time performing little actions without deliberation or inner uneasiness, such as the moments "in our idle hours or vacant spaces of time (when) we turn our eyes to look at a butterfly, or put down our hands to remove the flap of our waistcoat that had gotten between us and the chair” $(1768,1$, i, p. 101). Tucker parades examples, often from his own experience: "I speak only for myself: when I sit down to dinner I feel no uneasiness in being hungry, rather rejoice in having a good appetite” (pp. 126-7). Frequently, the expectation of pleasure itself can produce further pleasures, not uneasiness. When we are thirsty on a hot day, we may derive pleasure in seeing the wine sparkle as it is poured from a bottle, and in hearing “the little glug glugs” (p. 127).

There are no disquisitions on the psychological effects of glug glugs in Locke's Essay. But, as will be seen, the expectation of future pleasure (or pain) reflected something fundamental about human experience that Tucker stressed. Tucker denied that he differed from Locke substantially. They differed in their "manner of handling” the issues of action: "Though I do not pretend to a clearer, perhaps I may to a more 
microscopic eye: I consider action more minutely” (1768, 1, i, p.119). On a number of occasions, Tucker used the metaphor of a microscope to describe his mode of analysis. "We Searches”, he wrote, “although not many of us are clever at handling the telescope, are observed to be in general very fond of the microscope” (1843, p. 455). In essence, Tucker was defending the sort of method that a James or a Goffman would use: looking in detail at what people do and feel, rather than constructing a grand scheme and then searching for examples to fit the theory. Characteristically, Tucker laughed at his chosen metaphorical method. The microscope is not always useful: "if you walk in the street with a pair of microscopes tied to your eyes, you will perpetually be running against people” (1843, p. 459).

Tucker's method was not really a 'method' in the modern sense but he was engaging in what Ernest Hilgard would call 'psychologising'. To 'psychologise' was, in Hilgard's view, “to reflect on ordinary observations” and then to offer such a plausible interpretation that "detailed proof would seem irrelevant—or at least too tedious to be worth the effort” (1987, p. 50). According to Hilgard, James was the "the preeminent psychologiser"; and this is why James produced such "a full-bodied, warm-hearted psychology” (Hilgard, 1987, p. 50; see also Hunt, 1994). James, of course, was opposing the cold psychology of German introspectionism with a looser, more personal form of self-analysis (Myers, 1997). Some psychologists, notably Baldwin and Hall, criticised James’s Principles, when it was first published, for being too unsystematic and too personal (Henley, 2007; Richardson, 2007, pp. 301ff). When put alongside Locke's theory-driven descriptions of action (or those of Hartley), Tucker's accounts likewise convey a full-bodied, unsystematic, warm-hearted sense of humanity. 


\section{$\underline{\text { Stream of Thought }}$}

The parallels between Tucker and James would be interesting, but not necessarily crucial, if they were based solely on their stylistic similarities as writers. There is, additionally, a substantive similarity in the way the two understood the nature of consciousness. James’s most famous 'discovery' - namely that consciousness is a stream - has its parallels in Tucker's work.

Tucker's analysis of the mind differed from that of Locke (and also from later associationists) in one very important respect. Tucker did not use his metaphorical microscope to isolate particular states of mind which supposedly exist at a given instant. He saw actions and thoughts occurring over time and, thus, the mind had to be analysed in relation to sequential patterns of living. This is apparent in Tucker's descriptions of pleasure and uneasiness. The common occurrences that he described are actions taking place across time: we are hot and thirsty, sit down and wait for the drink to be poured etc. He is envisaging a sequence of events, rather than an isolated, psychological moment.

When discussing the anticipation of pleasure, Tucker wrote that the present moment does not really exist as such, for we are always looking forward. Although philosophers might talk of the present and claim that our will affects the present moment, "this present time is in reality the next succeeding instant” $(1768,1, \mathrm{i}, \mathrm{p}$. 108). This can be seen in the way we perceive things. Our perceptions "flow in upon us without intermission and we generally have a foresight of them before they come” 
(p. 109). Moreover, we can affect what we are about to see. In this regard, the future is mixed with the present. This was something that James emphasised, adding the past to the mixture of present and future. James wrote in Principles that the present only exists in an abstract sense, and that we do not have a consciousness of it (1890, vol. I, pp. 608f). Any perception of an object is complex and "part of the complexity is the echo of the objects just past, and, in a less degree, perhaps, the foretaste of those just to arrive” (p. 606).

For James, these notions of perception, involving past and present, follow from his famous conception of consciousness as a stream, whose existence he described as "the primal fact” of the science of psychology (1899, p. 15). James wrote that consciousness is unbroken and feels unbroken, although it can be interrupted when we sleep; otherwise “consciousness remains sensibly continuous and one” (1890, vol. I, p. 238). James could equally have repeated Tucker's description that perceptions flow in without intermission. James went on to stress that consciousness was not chopped up into bits: “A 'river’ or a 'stream' are the metaphors by which it is most naturally described". He declared that henceforth we should refer to "the stream of thought, of consciousness, or of subjective life” (p. 239, emphasis in original).

Tucker used the same metaphor. He argued that the mind is both active and passive. We cannot control our thoughts, even if we are deliberating upon an issue intently, rather than staring out of the window. The thinker is like a hound sniffing a trail: we might decide to follow the trail but we have not laid it down, so that we do not know where it might lead. The mind only begins a train of thinking "but the thoughts introduce one another successively” (1768, 1, i, p. 11). In this regard, Tucker says we 
can compare the thinker to a "man who has a river running through his grounds" (p. 12). The river might break into several channels; if the land-owner tries to dam up one of the channels, the river still flows through others. The flow of the river is unstoppable, and so it is with our thoughts which "are perpetually working so long as we are awake” (p. 13). We may divert our thoughts but we "can never totally prevent them from moving” (p. 13).

For James, the river of consciousness meant that thoughts and feelings never repeat themselves in exactly the same way: there is always movement. Tucker emphasised another point, from which James would not dissent: we are not in control of our thoughts. Our conscious life happens to us, as much, if not more, than we direct it to happen. The rational, dominant ego (or 'will') is a myth. We are not the masters (or mistresses) of our own minds: as Tucker wrote, “we cannot constantly keep a watchful eye on our thoughts” but notions will start up "in the fancy” (1768, 1, i, p. 370). According to Tucker, the mind "cannot lie a moment inactive" for "she works incessantly... and if her weightier motives suspend their action ever so little, some lighter will slip in to keep her in play” (1768, 1, i, p. 91). Some ideas are like lightning, they "flash, strike and vanish; they pass so swiftly we cannot get a look at them nor remember their existence” (p. 92).

Tucker was again departing from Locke, for he was denying that thinking or mental activity can be equated with consciousness. In one of the few passages from the Light of Nature to be quoted by a nineteenth century psychologist, Tucker wrote that the mind can continue working even when we are asleep. On waking, we can find that our ideas "have ranged themselves anew" and this shows that "our organs do not stand 
idle the moment that we cease to employ them” (1768, 1, i, p. 249). William Carpenter, the celebrated physiologist, quoted this passage to support his notion of ‘unconscious cerebration’ or brain activity giving rise to thinking without conscious experience (Carpenter, 1879, p. 531). By the time James was writing, it was becoming acknowledged that unconscious thinking not only existed but that its study was central to the new discipline of psychology. One American textbook, published five years after Principles, claimed that the largest class of mental activities, to be studied by psychologists, were unconscious ones (Krohn, 1895, p. 18). James, of course, had given great attention to our habits, fidgets, and the 'fringes of experience' of which we are largely unaware.

\section{The Importance of Habits}

There is another parallel between the ideas of Tucker and James: this is the importance that they paid to habits. It has been claimed that the chapter on habits is the most widely quoted chapter of Principles (Hothersall, 1984). James argued that much of our behaviour and experience is habitual. We develop habits of language, habits of mind, bodily habits etc. Some of our habits are 'known' by the body, not by the conscious mind: "Few men can tell off-hand which sock, shoe or trouser-leg they put on first". To remember, they must mentally rehearse the act and "even that is often insufficient - the act must be performed” (1890, vol. 1, p. 113). The habitual behaviour creates physiological connections and "habits diminish the conscious attention with which our acts are performed” (p. 112). 
There are also habits of mind, as well as body. It is through the development of perceptual habits that we come to understand the world. In a famous phrase, James described the world of the infant, who, assailed by all senses at once, perceives it all as just "one great blooming buzzing confusion” (1890, vol. 1, p. 488). Gradually, the infant learns to make sense of this confusion, selecting certain elements and ignoring others. This selectivity becomes habitual, as the mind, without conscious awareness, learns to focus on some elements and weed out others.

Conscious thinking also is guided by habits. Although James described thinking as a stream, thoughts pass before us "in a train or a chain” (1890, vol.1, p. 240). In this respect thought is jointed, as we pass from one train of thought to another (see Bailey, 1999, for a discussion of whether this conflicts with James's notion of the continuity of thinking). Because our brains are continually building up connections between nerves, so our minds build up habitual trains of thought; as we start thinking of one thing, so we move habitually to another. These conceptual habits ensure that we do not have to start from scratch each time we think. Thus, habits are conceptual, perceptual and behavioural. The individual could have no meaningful life without habits. Also, habits provide the routines that are vital for social life. In yet another striking phrase, James described habit as “the enormous fly-wheel of society” (1890, vol. 1, p. 121).

All these ideas - with the exception of the physiological speculations about the nervous system building up well-used connections - can be found in Tucker, who likewise saw habit as individually and socially crucial. He, too, envisaged the world of the infant as overloaded by confusing sensations. Nature presents her objects, he 
wrote, "in a chaos, or confused multitude, wherein there is nothing distinct, nothing connected”, as sights, sounds, smells, tastes and feelings "rush in all the five avenues of sensation, and accost the mind in one act of perception” (1768, 1, i, p. 223). The mind learns to select, to pay attention to some things not others - there is a "culling of particular objects from the whole number exhibited to view” (p. 225). And we begin to associate some objects with feelings, memories etc.

It is the same with thinking. Tucker paid great attention to the nature and operation of trains of thinking. He saw it as part of our nature to form and use trains: "Though the mind by her notice begins the formation of a train, there is something in our internal mechanism that strengthens and completes the concatenation” (1768, 1, i, p. 248). Once we have formed trains of thought then, "whatever suggests the first link, the rest will follow readily of their own accord” (p. 249). So, too, we might have behavioural habits; and Tucker discussed such small gestures of re-arranging a waistcoat or picking at one's fingers. Having chains of thought and habits were vital for life. Our first attempts at so many actions are awkward and slow, "while we are forced to dig up everything by dint of application”; but when we have formed "proper trains, that will spring up of their own accord', then we find 'we can go on expeditiously, readily and perfectly” (p. 254).

In Tucker's view, the importance of habit eclipses that of conscious judgement for the conduct of life, both on an individual and social level. He suggested: "The tenor of our lives, and success of our endeavours, depends more upon habit than judgement” (1768, 1, ii, pp. 93-4). Moreover, he claimed that "our habits both of thinking and acting” depend on the same cause, namely "the spontaneous or mechanical rising of 
ideas in thought” (1777, 3, iv, p. 175). Habit does not triumph by force, "but steals upon you imperceptibly, or teases or tires you into a compliance” (1768, 1, ii, p. 93). Because habits include our perceptions of objects, management of limbs, trains of thought and "common forms and modes of behaviour", then "there is no living in the world without falling into habits” (1777, 3, iv, p. 183).

Tucker may not have used the metaphor of the fly-wheel, but his meaning was similar to James. He had an additional argument that distinguished rules from habits. Rules, habits and customs share an affinity for "for they all tend to produce a uniformity of custom” (1777, iv, p. 246). We need rules for social life, but they are often irksome and restrictive. People react against them. However, habitual customs are far more efficacious than consciously followed rules. When rules become familiar, they cease to be consciously followed or resisted. Instead, they become "habits or ways of acting fallen currently into without care or reflection” (p. 246). Of course, some customs and habits can have ill consequences, such as the habits of prejudice or "habits of misapprehension and misjudging common among all degrees of men” (1777, 3, iv, p. 188). James pointed out that habit, the great social fly-wheel, was society’s "most precious conservative agent” (1890, Vol. 1, p. 121). Tucker appreciated that such conservatism had its dangers, as well as benefits. Habits, just like microscopes, can sometimes restrict our vision of the world.

The Significance of Tucker as a Jamesian

One can ask how significant are these parallels between James and Tucker, beyond suggesting that admirers of James might take a look at Tucker. Any answer needs to 
be considered alongside an obvious question: why has Tucker been forgotten? It is not sufficient merely to say, as Paley did, that the reason lies in the rambling nature of Tucker's great book. First, some thinkers have made and sustained reputations on the basis of long, unreadable works. Wilhelm Wundt provides one example. Second, a compact version of Light of Nature was published in 1807 by William Hazlitt, on the recommendation of the poet Coleridge. This abbreviated single volume fared no better than its much longer original. Certainly it was less successful than James’s compact version of Principles which was published under the title Psychology: briefer course (James, 1892). James was writing for an identifiable market of undergraduates who wanted accessible textbooks to help them through their courses. Neither Tucker nor Hazlitt had such a ready readership.

Perhaps Tucker was producing ideas that did not match the intellectual mood of his times. He was qualifying the notion that we can achieve a perfectly rational view of world. In effect, rather than by intention, Tucker was showing the psychological limitations of Locke's project of basing all knowledge on scientific reasoning. He was giving reasons why we are not in control of our minds. For much of the time, the conscious mind, or ego, was unaware of what it was doing. This did not represent a cognitive failure but was part of human nature. By the mid to late nineteenth century, developments in neuro-physiological research were suggesting that much brain activity does not reach conscious awareness. To use Carpenter’s term, ‘unconscious cerebration’ was becoming an acceptable idea. Moreover, writers such as Alexander Bain and Herbert Spencer were, in their analyses of the mind, paying attention to the little, non-intellectual, and even non-conscious, things that we do. The way was being 
prepared for accepting that 'the unconscious' may be an important determining factor in human psychology.

In wider historical and ideological terms, the dream of a perfectly rational, scientifically based enlightened world was looking increasingly implausible in the late nineteenth century. But before the French revolution, many intellectuals were reluctant to dethrone the rational ego. Much more historical investigation would be required in order to relate Tucker's lack of success to these wider movements of intellectual change. Yet, at first sight, he looks like a thinker, who proposed ideas that would appear significant a hundred years later, at least when presented with the rhetoric of scientific discovery, which even James employed.

Of course, forgotten figures can have intellectually important effects. One of the themes of Hidden Roots of Critical Psychology, is that the comparatively neglected figures of the third earl of Shaftesbury and Thomas Reid in the eighteenth century proposed psychological ideas, which are now returning to prominence (Billig, 2008). Moreover, Shaftesbury and Reid had an underground effect, for they set off a chain of important influences, although their initial contributions have tended to be overlooked. It is common for historically minded psychologists, who champion the cause of a neglected figure, to claim that the individual in question really did have a major impact. For example, the supporters of Karl Bühler, in arguing the case for reassessing his contribution, have stressed his influence on such major figures as Popper, Vygotsky and Wittgenstein (Wettersten, 1988; Brock, 1994). However, Tucker is a far more obscure figure than Shaftesbury, Reid or Bühler. There is no evidence that he directly influenced anyone in the league of Popper, Vygotsky or 
Wittgenstein. Certainly, Paley is not in that class today - and one would have to work hard at finding hidden links, in order to suggest that through Paley, Tucker has significantly affected the history of psychology.

There is, nevertheless, a possible almost-linkage between Tucker and James. This concerns the role of the English philosopher, Shadworth Hodgson. James and Hodgson first met in 1880 and then corresponded with each other. James quoted Hodgson's work extensively in Principles. Hodgson's philosophy was based on an analysis of mind and its operations. His approach was much more theoretical than James's and he certainly lacked the gift of illustration. In one letter to Hodgson, James complained that a piece of his friend's writing 'hangs in the air of speculation and touches not the earth of life' (30 December 1885, H. James, 1926, p. 244).

James was certainly influenced by Hodgson's ideas about consciousness. At one point in Principles, James included a lengthy quotation from Hodgson's Philosophy of Reflection (1878) to support his own notion that the perception involves past and future, giving consciousness its continuity "without which it could not be called a stream” (1890, vol. 1, p. 607). In the quotation, Hodgson suggested that in consciousness there is strictly no present and that experience is continuous. Hodgson did not describe consciousness as a stream in Philosophy of Reflection, nor in Theory of Practice (1870), which James also quoted in Principles. However, he did so in his first book, when he defined the purpose of metaphysics as tracing "the stream of consciousness and of existence to its source or sources” (Hodgson, 1865, p. 74). By the time he came to write Metaphysic of Experience (1898) several years after James’s Principles, Hodgson was using the metaphor regularly. 
More work would be needed to trace the influence of Hodgson on James and vice versa. What is of interest here is another possibility. There is no evidence that James read Tucker, but he certainly read Hodgson's Theory of Practice and, particularly, the sections on emotion (see James, 1890, vol.1, p. 130). In Theory and Practice, Hodgson gives a lengthy and critical discussion of Tucker's approach to the emotions (1870, pp.108ff). Hodgson was criticising the notion that emotions could be causes of other emotions or of physiological states. Although he clearly was familiar with Tucker's work, Hodgson does not cite him when discussing the continuity of consciousness or the absence of a pure experience of the present. One might speculate whether on these matters Tucker might have influenced Hodgson unconsciously. Although it is not possible to tie down any possible influence Tucker might have had on Hodgson - and then through Hodgson on James - one thing can be said. It would have been possible for Hodgson to have cited Tucker, where he tended to agree with him, and not just when he disagreed. Had he done so, James might then have become aware of his predecessor. We might speculate further. The seriously dry Hodgson would not have enjoyed the glug-glug, Miss Gawkey side of Tucker. James, on the other hand, would have been more appreciative. Such conjectures must remain, as Tucker described his vision of Locke, "hypotheses...concerning things unknown” (1768, 2, ii, p. 5).

Perhaps searching for the hidden influences that Tucker may have had on subsequent psychologists is to miss the point, at least for those critical of the present state of psychology. Critics need heroic forerunners who have not been implicated in creating the sort of psychology that they are now rejecting. Being forgotten then can then 
become an estimable quality. Accordingly, there is less need to argue that a forgotten figure really was important because they influenced the heavyweight stars. Tucker was an original, idiosyncratic writer. This is should be sufficient reason for celebration.

This is particularly so, if we wish to free psychology from the twin grip of theory and methodology, which psychologists often believe their discipline to be based upon. The enduring popularity of William James shows the poverty of the theorymethodology outlook. James was not a great theorist - the fame of Principles does not rest upon its presenting a unique theoretical stance. Nor did James present himself as a great enthusiast for methodology. Regarding the new experimental method, which was coming out of Germany, he wrote that it "taxes the patience to the utmost and could hardly have arisen in a country whose natives could be bored” (1890, vol. 1, p. 192, emphasis in original).

Psychology has to be more than theory and method. Like any academic discipline it must be written. It rhetoric is just as much, if not more, a part of its character as are its theories and methodologies. The critique of psychology's rhetoric is fundamental to any critique of the discipline (Bazerman, 1987 and 1988; Billig, 1994 and 1996). The examples of James and Tucker show why. James was a psychological writer. He disdained the conventional rhetoric of the research report, and instead dazzled, charmed and entertained his readers. His 'psychologising' was not a method as such. It could not exist outside of his writing, like the equipment of a psychological laboratory. His way of writing ensured that his psychologising was warm-hearted and humane. So it was with Tucker. The focus on the little things that we do, on the 
trouser-leg and the waistcoat flap, on understanding our all too human failings, on describing closely and wittily our ways of thinking - all these things bring the reader close to the writer.

If we want a warm-hearted, humane psychology, then it is not principally to theory or methodology that we should be turning. It is precisely because James and Tucker did not write like 'proper' psychologists that their writings are able to bring such insight and wisdom across the years. In celebrating these writers, and in using the one to recommend the other, we are not just celebrating psychology’s past. We are also raising the hope for a different future psychology. In a general sense, we will also be dismissing the present, whose psychological reality both Tucker and James, in any case, likewise dismissed. 
Endnote

1. All quotations from The Light of Nature Pursued are taken from the original editions, except for quotations from the chapter 'Word or Logos'. Judith Tucker omitted this chapter from the posthumously published third volume, fearing that readers might interpret it as lending support for Unitarianism. The chapter was reinstated subsequently with the approval of Tucker's grandson. Quotations from this chapter here are taken from the 1843 edition. 


\section{References}

Allen, R.C. (1999). David Hartley on Human Nature. Albany, N.Y.: State University of New York Press.

Angell, J.R. (1996). William James. In L. Simon (ed.), William James Remembered (pp. 131-3). Lincoln: University of Nebraska Press,.

Annual Register of the history, politics and literature for the year 1775. (1777). London: J. Dodsley.

Bailey, A.R. (1999). Beyond the fringe: William James on the transitional parts of the stream of consciousness. Journal of Consciousness Studies, 6, 141-153.

Baldwin, J.M. (1913). History of Psychology. London: Watts \& Co.

Bazerman, C. (1987). Codifying the social scientific style: the APA Publication Manual as behaviourist rhetoric. In J.S. Nelson, A. Megill and D.N. McCloskey (eds), The Rhetoric of the Human Sciences (pp.125-144). Madison: University of Wisconsin Press.

Bazerman, C. (1988). Shaping Written Knowledge. Madison: University of Wisconsin Press.

Billig, M. (1994). Repopulating the depopulated pages of social psychology. Theory and Psychology, 4, 307-335.

Billig, M. (1996). Arguing and Thinking. Cambridge: Cambridge University Press.

Billig, M. (2008). The Hidden Roots of Critical Psychology. London: Sage.

Boring, E.G. (1929). A History of Experimental Psychology. New York: AppletonCentury. 
Brock, A. (1994). What ever happened to Karl Bühler? Canadian Journal of Psychology, 35, 319-329.

Carpenter, W.B. (1879). Principles of Mental Physiology. London: C. Kegan Paul. Crawford, B.V., Kern, A.C. and Needleman, M.H. (2007). American Literature. New York: Barnes and Noble.

Damasio, A. (2006). Descartes’s Error. London: Vintage.

Glassman, R.B. and Buckingham, H.W. (2007). David Hartley’s neural vibrations and psychological associations. In H. Whitaker, C.U.M. Smith and S. Finger (eds), Brain, Mind and Medicine (pp. 177-190). New York: Springer.

Goodwin, J.C. (2004). A History of Modern Psychology. Hoboken, N.J.: John Wiley.

Gregory, R.L. (1994). Even Odder Perceptions. London: Routledge.

Hartley, D. (1749/1834). Observations on Man, his frame, his duty and his expectations. London: Thomas Tegg.

Hazlitt, W. (1807). An Abridgement of 'The Light of Nature Pursued' by A. Tucker. London: J. Johnson.

Henley, T.B. (2007). Remembering William James. In A. Brook (ed.), The Prehistory of Cognitive Psychology (pp. 205-229). London: Palgrave Macmillan.

Hergenhahn, B.R. (2001). An Introduction to the History of Psychology. London: Wadsworth Thomson Learning.

Hilgard, E.R. (1987). Psychology in America. San Diego: Harcourt Brace Jovanovich. Hodgson, S.H. (1865). Time and Space. London: Longman Green.

Hodgson, S.H. (1870). The Theory of Practice. London: Longmans, Green, Reader and Dyer.

Hodgson, S.H. (1878). The Philosophy of Reflection. London: Longmans, Green and Co. 
Hodgson, S.H. (1898). The Metaphysic of Experience . London: London: Longmans Green.

Hothersall, D. (1984). History of Psychology. Philadelphia: Temple University Press.

Hunt, M. M. (1994). The Story of Psychology. New York: Doubleday.

James, H. (ed.) (1926). The Letters of William James. Boston: Little, Brown and Co

James, W. (1890). The Principles of Psychology. London: Macmillan.

James, W. (1892). Psychology: briefer course. London: Macmillan.

James, W. (1899). Talks to Teachers on Psychology. Longmans Green.

James, W. (1902). Varieties of Religious Experience. Longmans Green.

James, W. (1908). The Will to Believe. London: Longmans Green.

James, W. (1911). Memories and Studies. London: Longmans Green..

Krohn, W. O. (1895). Practical Lessons in Psychology. Chicago. Werner.

Leary, D.E. (1990). William James on the self and personality: clearing the ground for subsequent theorists, researchers and practitioners. In M.G. Johnson and T.B. Henley (eds), Reflections on the Principles of Psychology (pp. 101-137). Hillsdale, N.J.: L. Erlbaum.

Locke, J. (1690/1960). An Essay Concerning Human Understanding. London: Fontana.

Martin, R. and Barresi, J. (2000). Naturalization of the Soul. London: Routledge.

Mildmay, H. P. St. J. (1831). Some account of the life of Abraham Tucker, Esq. In A. Tucker, The Light of Nature Pursued, volume 1 (pp. v-xxx). Cambridge: Hilliard and Brown.

Münsterberg, H. (1996). Professor James as a psychologist. In L. Simon (ed.), William James Remembered (pp. 109-110). Lincoln: University of Nebraska Press. 
Myers, G.E. (1997). Pragmatism and introspective psychology. In R.A. Putnam (ed.), The Cambridge Companion to William James (pp. 11-24). Cambridge: Cambridge University Press.

Paley, W. (1791). The Principles of Moral and Political Philosophy. London: R. Fauldner.

Richards, G. (2002). Putting Psychology in its Place. London: Routledge.

Richardson, R.D. (2007). William James: In the maelstrom of American modernism. Boston: Mariner.

Robinson, D.N. (1996). An Intellectual History of Psychology. Madison: University of Wisconsin Press.

Schiller, F.C.S. (1996). William James. In L. Simon (ed.), William James Remembered (pp. 139-141). Lincoln: University of Nebraska Press.

Taylor, C. (2002). Varieties of Religion Today: William James revisited. London: Harvard University Press.

Tucker, A. (Anon.) (1775). The Country Gentleman's Advice to his Son. London: W. Owen.

Tucker, A. (Search, E.) (1763a). Freewill, Foreknowledge and Fate, a fragment. London: R. and J. Dodsley.

Tucker, A. (Comment, C.) (1763b). Man in Quest of Himself. London: R. and J. Dodsley.

Tucker, A. (Search, E.) (1768). The Light of Nature Pursued. London: T. Payne. Tucker, A. (Search, E.). Vocal Sounds. London: T. Payne.

Tucker, A. (1777). The Light of Nature Pursued by Edward Search, volume III: the posthumous work of Abraham Tucker. London: T. Payne and Son.

Tucker, A. (1843). The Light of Nature Pursued, volume 2. London: Henry Bohn. 
Ulmer, W.A. (2006). The alienation of the elect in Coleridge's Unitarian prophecies. Review of English Studies, 57, 526-544.

Wade, N.J. (2005). The persisting vision of David Hartley. Perception, 34, 1-6.

Wertheimer, M. (1987). A Brief History of Psychology. London: Holt, Rinehart and Winston.

West, R. (1916). Henry James. New York: Henry Holt.

Wettersten, J. (1988). Kulpe, Bühler, Popper. In A. Eschbach (ed.), Karl Bühler’s Theory of Language (pp. 327-347). Amsterdam/Philadelphia: John Benjamins. Wozniak, R. H. (1999). Classics in Psychology, 1855-1914. Bristol: Thoemmes Press. Young, B. W. (2004). Tucker, Abraham (1705-1774). In Oxford Dictionary of National Biography. Oxford: Oxford University Press. 